\title{
Uncovering Indonesian Millennial's Halal Food Purchase Intention: Halal Value And Halal Logo As The Antecedents
}

\author{
Adila Sosianika ${ }^{\mathrm{a}}$ and Fatya Alty Amalia ${ }^{\mathrm{b} *}$ \\ ${ }^{\mathrm{a}, \mathrm{b}}$ Lecturer, Department of Business Administration, Politeknik Negeri Bandung, Indonesia
}

Received 19 January 2020; accepted 28 January 2020

\begin{abstract}
This study attempts to uncover the Millennial's decisional factors in purchase intention of Halal food in Indonesia, while heavily considering Halal food as a credence consumer good. After an analysis of 248 respondents using PLS-SEM, several interesting findings were obtained. Millennial's understanding of Halal Value and Halal Logo serves as the antecedents of Purchase Intention of Halal food which is mediated by Attitude and Trust. Further analysis was also carried out by examining the moderating effect of gender with Multi-Group Analysis. As the result, the distinct paths and significant difference of effects can be spotted on the female and male groups which shall provide deeper insights to any relevant stakeholders, especially food providers.
\end{abstract}

\section{KEYWORDS}

Millennials

Trust

Halal value

Halal logo

Purchase intention

\section{INTRODUCTION}

Among all generations, today's spotlight is heavily put on the Millennials, those who are born in the 1980s-199os (Jang et al., 2011). Living in different situation and condition from other generations has brought Millennials up with typical characteristics, such as a tech-savvy, greatly consumptive, and trendsetter oriented (Marmaya et al., 2019). Such typical characteristic of Millennials is perceived to be distinct from others as each generation lives in different value system from diverse settings (Marmaya et al., 2019). Since Millennials with their great buying power are being the promising consumer group at present (Pomarici \& Vecchio, 2014), a large endeavor is required to fully captivate this group for making a purchase. As today's information technology has facilitated information sharing in a tremendously swifter way (Valentine \& Powers, 2013), Millennials can obtain more alternatives of brands and have poor loyalty over a brand (Lissitsa \& Kol, 2016; Saeed \& Azmi, 2019).

Another fact arising from Millennials is that they are not only perceived as the largest population worldwide within the age cohort (Fry, 2018) but also within the religious group. The domination of Millennials groups can be clearly seen in the Muslim population, the worldwide largest population, and this puts Millennials Muslim as the noteworthy consumer group (Reuters, 2018).

For a Muslim Millennial, Halal becomes a vital matter since it is directly regulated in Islamic law (Ali, Xiaoling, Sherwani, Ali, 2017; Mukhtar and Butt, 2012; Arham, 2010;

*Corresponding Author: fatya.alty@polban.ac.id; doi: 10.35313/ijabr.v2io1.91

(C) 2020 Politeknik Negeri Bandung 
Thomas and Selimovic, 2015). Halal food naturally becomes the only consumption preference of any Muslim Millennial. As the consequence, this generation becomes its promising customers. However, existing researches still put few spotlight over this generation. Such surprising occasion indicates that a poor determination of Muslim Millennials might exist in a Muslim majority country, like Malaysia. The Islamic law regarding Halal food seems to be not entirely applied in the Malaysian younger generation (Marmaya et al., 2019). According to the study, there are no guilty feelings they show while eating at a non-Halal restaurant. As Indonesia is recognized being similar with Malaysia, in the term as Muslim majority country, Indonesian Millennial consumer group is worth to examine as well.

This paper aims to examine Muslim Millennials' purchase intention on Halal certified food in Indonesia. This study is worth to carry out since Indonesia has been recognized wherein the largest Muslim population live and has offered the promising Muslim market worldwide. A great concern of Halal food as a credence good has led the authors to include trust, halal value, and halal logo besides attitude in giving broader view of Millennial's purchase intention of Halal certified food. This study is written structurally as follows. The second section presents the literature reviews by paying attention to extant studies. In the third section, methodology is disclosed to support the credibility of the findings. Results of data analysis are shown at the fourth section and be discussed further in the fifth section, i.e. discussion part. To provide a better summary of this study, conclusion, managerial implication, and limitation are provided in the sixth section and so on.

\section{LITERATURE REVIEW}

\section{Attitude}

Attitude is recognized as the favorable evaluation of someone on performing a behavior according to the Theory of Planned Behavior (TPB) promoted by Ajzen (1985). In general, TPB explains that a behavior someone carries is influenced by his or her behavioral intention. The intention itself can be developed as it is determined by the volitional (i.e. attitude and subjective norm) and non-volitional dimensions (i.e. perceived behavioral control) (Bashir et al., 2019; Holdsworth et al., 2019). This study puts more spotlights on attitude as the antecedent of purchase intention on Halal food. The application of TPB in Halal food industry has been widely used for a long time, such as (Ali et al., 2018; Sherwani et al., 2018; Vanany et al., 2019). These studies confirmed that someone's attitude can influence the purchase intention of Halal food. It means that once the attitude increases at a certain level, so does the purchase intention.

\section{$\mathrm{H}_{1}$ : Attitude positively affects Purchase intention on Halal-certified food}

The consumer's purchase decision is an activity which obviously involves a proper understanding or knowledge over the product's utility and may be able to confirm the utility claim after the purchasing occurs. Seeing this situation, a producer seems often to be quite superior at the information comprehending rather than a consumer. In fact, the consumer in many cases cannot easily observe the claims of attributes at both prior and after purchase, which leads to unsymmetrical information between producer and consumer. Regarding the easiness of observing the claim of attributes, Ishak et al. (2016) further arrange the consumer goods into three types, namely searched, experienced, and credence consumer goods. First, the 
searched goods are goods in which the consumer may easily observe the attributes both at prior and after purchase, for instance, clothing and books. Second, the experienced goods allow the consumer to fully observe the attributes only after the purchase, not at the prior purchase, for example, traveling and beauty salons. The last, the credence goods. This type of goods completely does not permit the consumer to observe the attributes not only at prior but also after purchase.

The food industry is an instance of credence goods since the consumers cannot observe the real ingredients of foods prior to purchase and after consumption (Ishak et al., 2016; Perrini et al., 2010). Such condition surely also happens to Halal food which even getting harder for consumers to observe the Halal status just by looking at a glance. Halal is an intangible value that is unobservable and complex, so it is rather difficult for consumers to confirm the status of Halal within a Halal food. For that reason, the marketing of Halal foods is required to provide an assurance to convey the message of the firm upon the existence of Halal feature within the foods (Ishak et al., 2016). As mentioned previously, the unsymmetrical information strongly emerges in credence goods. Only the producers truly know the Halal status of their Halal-claimed foods, while the consumers tend to count on their perception developed by the information from the various indicators (Ishak et al., 2016).

By addressing Halal food characteristic as a credence good, this study includes other relevant variables besides Attitude to provide more extensive explanation about the consumers' purchase intention on Halal food. Those variables are Trust, Halal Logo, and Halal Value.

\section{Trust}

The credence attribute in the food products has put the trust of consumers as a notable facet which needs further attention of the food providers. Trust means putting a positive expectancy over the vulnerability of the trustee (Del Giudice et al., 2018; Nuttavuthisit \& Thøgersen, 2017). By having trust, the uncertain assumption over the claim of products which resides in consumer's mind may disappear and lead them to purchase those credence goods (dos Santos \& Fernandes, 2008; Mohamed et al., 2013). An obvious instance regarding this claim can be seen in the case of organic food studied by Teng \& Wang (2015). Despite customers' difficulty in proving its organic claim, through trust the consumers are still willing to purchase the organic food (Teng \& Wang, 2015).

Presumably, Halal food may undergo a similar situation as organic food since both are credence goods. Consumers may rely on their trust upon the claim of Halal status mentioned by the providers through Halal logo which is attached to the package (Mohamed et al., 2013). Even, the trust over Halal logo is getting necessary to require as the consumers purchase Halal foods from retailers, not from providers directly (Verbeke et al., 2013). On the other hand, the Millennials are of the well-educated consumers who also show greater long-term concerns in most of all their purchases, such as health, community, and environmental issues ( $\mathrm{Lu}$, Bock \& Joseph, 2013; Spehar, 2006). By trusting the value of Halal food, Millennial consumers may perceive that it is away from any food safety issues (Lu et al., 2013) and Halal logo may assure the Halal status throughout the supply chain (Nuttavuthisit \& Thøgersen, 2017). With this information, this study indicates that the Millennial's trust over Halal-certified food will be critical to shape their attitude and purchase intention (Bouhlel et al., 2011).

$\mathrm{H}_{2}$ : Trust positively affects Attitude of Halal-certified food

$\mathrm{H}_{3}$ : Trust positively affects purchase intention of Halal-certified food 


\section{Halal logo}

Today's quality concept of food is getting wider which may lead to a challenging task in confirming the credence attributes of the food (Del Giudice et al., 2018). In the credence goods, accessible and true information turn out to be a crucial thing in determining the consumer's purchase decision (Abdul Latiff et al., 2016; Teng \& Wang, 2015). The consumers can possibly acquire information from valid certification which acts as a communication tool of provider in delivering message about the quality of credence goods (Bonne \& Verbeke, 2008; Del Giudice et al., 2018; Sheldon, 2017). The certification may also help the consumers reduce any possible risks regarding the product's quality (Muhamad et al., 2017), for instance, the revealed information on credence goods, i.e. organic food, can influence the consumers' attitude and trust in organic foods (Teng \& Wang, 2015).

A similar concept shall occur in Halal food as well. The claim of Halal becomes credible once Halal logo is attached to the food package as a symbol of acquiring Halal certification from the authorized Halal certifying body. Due to the existence of Halal logo, the consumers can verify the claim which has indeed complied with Islamic standards in terms of ingredients and processing (Tieman, 2011). A past study (Golan et al., 2001) confirms that Halal logo can help the British Muslims keep informed about Halal status while buying foods in the Muslimminority community (Jamal \& Sharifuddin, 2015).

$\mathrm{H}_{4}$ : Halal logo positively affects attitude

$\mathrm{H}_{5}$ : Halal logo positively affects trust

\section{Halal Value}

Halal principle regulates any matters permissible for Muslims according to Islamic teaching (Haque et al., 2015). A clear application of Halal is seen in food in which a Muslim must avoid consuming "hazardous" things, though the concept is not limited to food matter only. Since Halal principle demands the food producers to produce foods with healthy diets (i.e. Toyyib) as well as hygiene and clean environment from farm to fork, the perception of Halal food relates to a good standard of safety, health, and quality aspects, naturally resides in Muslim even nonMuslim consumers (Majid et.al., 2015; Janis, 2004). A study by Golnaz et al. clarifies that Russian non-Muslims assume that due to the devout of Muslim food producers, it is less likely for them to not obey Halal principles while making Halal foods (Haque et al., 2015). This study might show a strong trust towards the claim of Halal status. On the other hand, a good perception of Halal value which resides in consumer's minds may lead to a heavier consideration of Halal logo rather than other certifications in a food product (Ayyub, 2015; Majid, et al., 2015). Moreover, when Halal food can deliver its promise of values to consumers consistently, accordingly it will also enhance the consumer's trust (Borzooei and Asgari, 2013; Delgado-Ballester \& Munuera-Alemán, 2005).

\section{$\mathrm{H}_{6}$ : Halal value positively affects Halal logo \\ $\mathrm{H}_{7}$ : Halal value positively affects attitude. \\ $\mathrm{H}_{8}$ : Halal value positively affects trust.}

This study does not only examine the relationships among those five variables mentioned previously, yet it also examines a moderating variable, i.e. gender, as shown in Figure 1. 


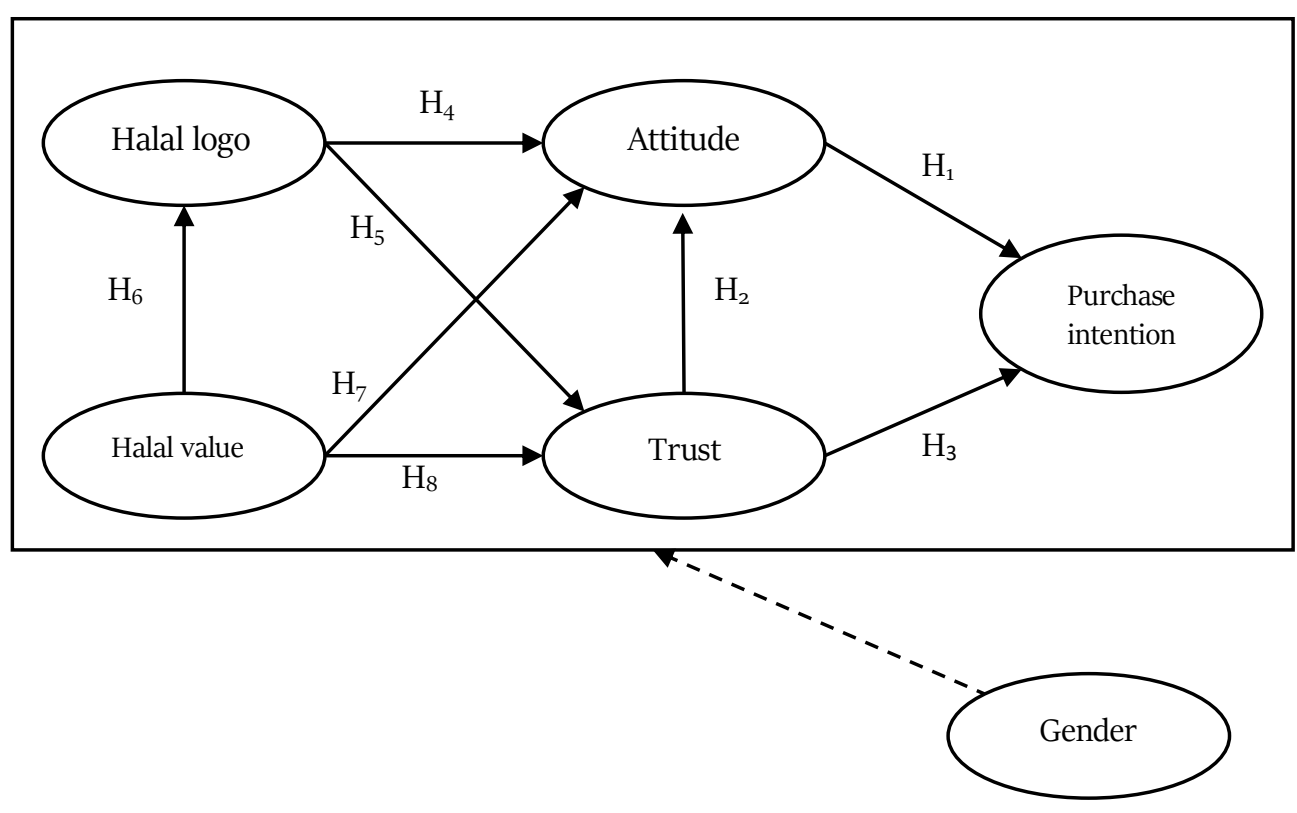

Figure 1. Millennials' purchase intention towards Halal food

\section{RESEARCH METHODS}

To satisfy the aim of the study, a survey method was conducted for data collection stage. The survey was carried out by spreading a set of questionnaires (online and offline) which consisted of 13 questions adopted from past studies by (Miharja, 2017; Teng \& Wang, 2015; Vanany et al., 2019) in order to describe five variables as shown in Table 2. It also employed five points- Likert scale ( 1 indicated strongly disagree -5 indicated strongly agree) to measure the response of each question. In addition, the questionnaire was designed in Bahasa Indonesia to overcome the language barrier during data collection. A pilot test to 33 respondents was carried out to ensure the readability and legibility of the questionnaire prior to the real data collection (Suhartanto et al., 2019).

With two months period of data collection (July-August 2019), this study successfully collected 248 responses from Millennial consumer group (born in 1980-200o) with purposive sampling. Due to this sample size, this study apparently passed the prerequisite of examining the model using PLS-SEM with smartPLS 3.0 (Hair et al., 2016). PLS-SEM analysis was chosen since it can test the latent variables regardless of normality and sample size issues (Chin et al., 2008). By and large, an analysis with PLS-SEM requires two stages consecutively, i.e. measurement model and structural model (Dean, Suhartanto, \& Kusdibyo, 2019). In the measurement model, the analysis focuses on evaluating the reliability and validity of the measurements of variables., Meanwhile, the structural model will examine the hypotheses set within the proposed conceptual model. This study also carried out a multi group analysis (MGA) by using gender as the moderating variable. 


\section{RESULTS}

The demographics of 248 respondents participating in this study are shown in Table 1.

Table 1. Demography of respondents

\begin{tabular}{llcc}
\hline Gender & & Frequency & $\%$ \\
\hline & Female & 149 & 60.08 \\
& Male & 99 & 39.92 \\
\hline Occupation & & \\
\hline & Student & 73 & 29.44 \\
& Government employee & 44 & 17.74 \\
& Private employee & 94 & 37.90 \\
& Entrepreneur & 17 & 6.85 \\
& Other & 20 & 8.07 \\
\hline Monthly income (IDR) & & & \\
\hline & $<1.5$ million & 65 & 26.21 \\
& $1.5-2.9$ million & 53 & 21.37 \\
& $3-5$ million & 54 & 21.77 \\
& $>5$ million & 76 & 30.65 \\
\hline
\end{tabular}

\section{Measurement Model}

All 13 questions in the questionnaire are at the acceptable level of good reliability and validity in regards to factor loading ( $\geq 0.7$ ), composite reliability ( $\geq 0.7$ ), Cronbach's $\alpha(\geq 0.7$ ), and Fornell \& Larcker criterions as outlined in Table 2 and 3.

Table 2. Loading, Reliability, and AVE of variables

\begin{tabular}{|c|c|c|c|c|c|}
\hline Variables & Indicators & $\begin{array}{l}\text { Factor } \\
\text { loading }\end{array}$ & $\begin{array}{c}\text { Cronbach's } \\
\alpha\end{array}$ & $\begin{array}{l}\text { Composite } \\
\text { Reliability }\end{array}$ & AVE \\
\hline Halal logo & & & 0.705 & 0.871 & 0.772 \\
\hline L1 & $\begin{array}{l}\text { Halal food logo can truly ensure } \\
\text { Halal status of food }\end{array}$ & 0.881 & & & \\
\hline $\mathrm{L} 2$ & $\begin{array}{l}\text { Halal food logo can make me feel } \\
\text { safe eating Halal food }\end{array}$ & 0.876 & & & \\
\hline Attitude & & & 0.871 & 0.921 & 0.796 \\
\hline At1 & $\begin{array}{l}\text { For me eating Halal certified food is } \\
\text { important }\end{array}$ & 0.905 & & & \\
\hline At2 & $\begin{array}{l}\text { For me eating Halal certified food is } \\
\text { desired }\end{array}$ & 0.885 & & & \\
\hline Trust & & & 0.776 & 0.869 & 0.689 \\
\hline $\mathrm{T} 1$ & $\begin{array}{l}\text { I trust institutions that issue Halal } \\
\text { certificates }\end{array}$ & 0.798 & & & \\
\hline $\mathrm{T} 2$ & $\begin{array}{l}\text { I trust the quality of Halal certified } \\
\text { food }\end{array}$ & 0.860 & & & \\
\hline T3 & $\begin{array}{l}\text { I trust the brands selling Halal } \\
\text { certified food do sell good quality of } \\
\text { food }\end{array}$ & 0.830 & & & \\
\hline
\end{tabular}


Table 2. Loading, Reliability, and AVE of variables (continued)

\begin{tabular}{|c|c|c|c|c|c|}
\hline Variables & Indicators & $\begin{array}{l}\text { Factor } \\
\text { loading }\end{array}$ & $\begin{array}{c}\text { Cronbach's } \\
\alpha\end{array}$ & $\begin{array}{l}\text { Composite } \\
\text { Reliability }\end{array}$ & AVE \\
\hline Halal value & & & 0.813 & 0.914 & 0.842 \\
\hline V1 & $\begin{array}{l}\text { When compared to non-Halal } \\
\text { food, Halal food is better in } \\
\text { quality }\end{array}$ & 0.909 & & & \\
\hline V2 & $\begin{array}{l}\text { Compared to non-Halal food, } \\
\text { Halal food is healthier and safer } \\
\text { to consumer }\end{array}$ & 0.926 & & & \\
\hline $\begin{array}{l}\text { Purchase } \\
\text { intention }\end{array}$ & & & 0.767 & 0.866 & 0.682 \\
\hline PI1 & $\begin{array}{l}\text { I am willing to pay more when } \\
\text { consuming Halal certified food }\end{array}$ & 0.821 & & & \\
\hline $\mathrm{PI} 2$ & $\begin{array}{l}\text { I am willing to buy Halal certified } \\
\text { food if available }\end{array}$ & 0.833 & & & \\
\hline $\mathrm{PI}_{3}$ & $\begin{array}{l}\text { I am willing to consume Halal } \\
\text { certified food as a daily food }\end{array}$ & 0.824 & & & \\
\hline
\end{tabular}

Table 3. Discriminant validity of variables (Fornell \& Larcker criterion)

\begin{tabular}{lccccc}
\hline & Attitude & Halal logo & Halal value & Purchase intention & Trust \\
\hline Attitude & 0.892 & & & & \\
Halal logo & 0.494 & 0.879 & & & \\
Halal value & 0.428 & 0.419 & 0.918 & & \\
Purchase intention & 0.383 & 0.403 & 0.368 & 0.826 & \\
Trust & 0.477 & 0.673 & 0.494 & 0.381 & 0.830 \\
\hline
\end{tabular}

\section{Structural Model}

After confirming that the result of the measurement model is at the satisfying level, testing all hypotheses drawn in the stage of the structural model was conducted. For this stage, the analysis was carried out for two types of data; all respondents and gender-group analysis (MGA). Table 4 outlines that all hypotheses are accepted either at $\mathrm{p}<0.01$ and $\mathrm{p}<0.05$. For detail, Millennials' purchase intention of Halal food is significantly affected by purchase trust $(\beta=0.256, p<0.01)$ and attitude $(\beta=0.261, p<0.01)$. Attitude is significantly influenced by Halal Logo $(\beta=0.281, p<0.01)$, Halal value $(\beta=0.223, p<0.01)$, and Trust $(\beta=0.177, p<0.05)$. Meanwhile, Halal Value $(\beta=0.257$, $\mathrm{p}<0.01)$ and Halal $\operatorname{logo}(\beta=0.565, \mathrm{p}<0.01)$ also successfully act as the independent variables of Trust. Halal value is deemed as a notable variable as it serves as the independent variable for not only Trust and Attitude but also for Halal Logo $(\beta=0.419, \mathrm{p}<0.01)$.

On the other hand, the possible indirect effects are considered herein as well. Regarding that, this study discovered several partial mediations worth to pay attention. First, trust serves as the mediator with a partial mediating effect for the relationship between Halal Logo and Attitude. Second, partial mediation is shown as well in the relationship between Halal Value and Attitude in 
which Halal Logo and trust act as the mediators. Third, in a way of Halal Value affecting Trust, there is Halal Logo that mediates this relationship; hence a partial mediation also applies herein. However, Table 4 shows that there is no mediating effect of attitude in the relationship between Trust and Purchase Intention. In addition, Halal logo and Halal value are proven to indirectly affect Millennials' purchase intention on Halal food through Trust and Attitude. From Figure 2, this model can explain $19.1 \%$ of Purchase Intention, $31.1 \%$ of Attitude, $50.3 \%$ of Trust, and $17.2 \%$ of Halal Logo.

As this study performs the indirect effect analysis as well, this model describes that there are partial mediators in terms of $\mathrm{f}^{2}$. The small effect $\left(\mathrm{f}^{2}>0.02\right)$ exists in the following relations (Hair et al., 2016):

- Attitude (0.066) and Trust (0.063) toward Purchase intention

- Halal logo (0.063), halal value (0.054), and trust (0.023) toward attitude

- Halal value (0.110) towards trust

Meanwhile, the large effects $\left(f^{2}>0.35\right)$ occurs in Halal value (o.213) towards Halal logo and Halal logo (0.534) towards trust (Hair et al., 2016). Regarding $Q^{2}$, all dependent variables of this study possess greater value $\left(\mathrm{Q}^{2}>0\right)$ which indicates that the predictive power of the model exists (Hair et al., 2016).

Table 4. PLS result for all respondents

\begin{tabular}{lccc}
\hline \multicolumn{1}{c}{ Hypothesis } & \multicolumn{3}{c}{ All respondents } \\
\cline { 2 - 4 } & Direct effect & $\begin{array}{c}\text { Indirect } \\
\text { effect }\end{array}$ & Total effect \\
\hline Attitude $\rightarrow$ Purchase intention & $0.261^{* *}$ & - & $0.261^{* *}$ \\
Halal logo $\rightarrow$ Attitude & $0.281^{* *}$ & $0.100^{*}$ & $0.382^{* *}$ \\
Halal logo $\rightarrow$ Trust & $0.565^{* *}$ & - & $0.565^{* *}$ \\
Halal logo $\rightarrow$ Purchase intention & - & $0.244^{* *}$ & $0.244^{* *}$ \\
Halal value $\rightarrow$ Attitude & $0.223^{* *}$ & $0.206^{* *}$ & $0.428^{* *}$ \\
Halal value $\rightarrow$ Halal logo & $0.419^{* *}$ & - & $0.419^{* *}$ \\
Halal value $\rightarrow$ Trust & $0.257^{* *}$ & $0.237^{* *}$ & $0.494^{* *}$ \\
Halal value $\rightarrow$ Purchase intention & - & $0.238^{* *}$ & $0.238^{* *}$ \\
Trust $\rightarrow$ Attitude & $0.177^{*}$ & - & $0.177^{*}$ \\
Trust $\rightarrow$ Purchase intention & $0.256^{* *}$ & 0.046 & $0.302^{* *}$ \\
\hline
\end{tabular}

Note: ${ }^{* *} p<0.01$; ${ }^{*} p<0.05$ 


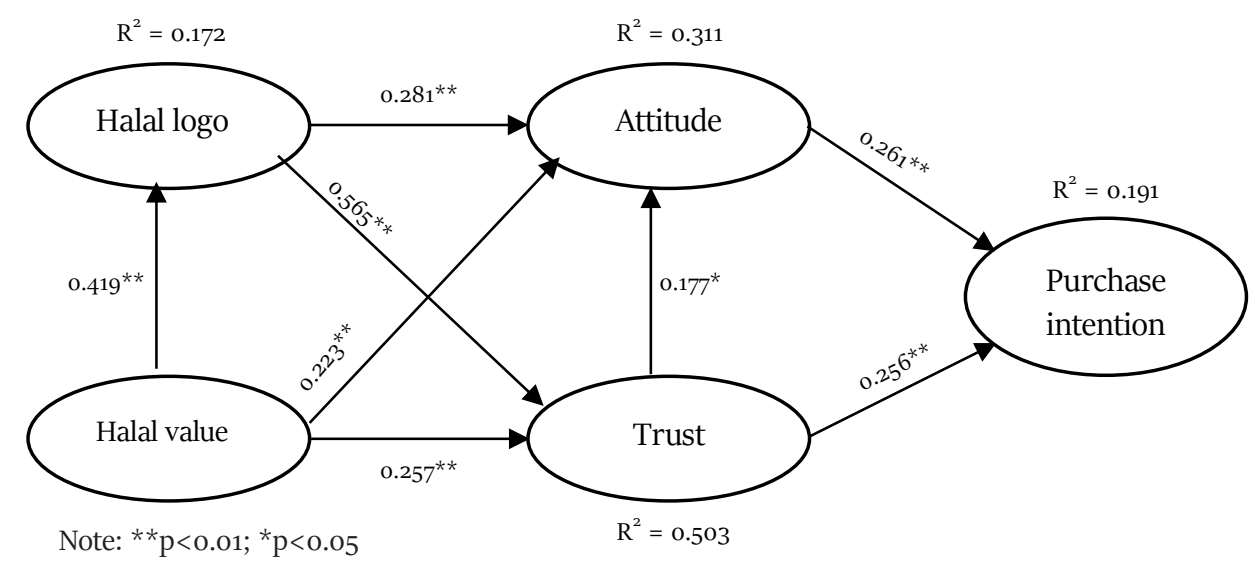

Figure 2. PLS results of all respondents

\section{The Moderating Role Of Gender}

This study also attempts to examine the model based on gender as the moderating variable. Some interesting findings were successfully generated as shown in Figures 3 and 4 . For female Millennial consumers, Halal value does not directly affect Attitude. The similar result also occurs in the case of Attitude toward Purchase Intention. Yet, the rest of the hypotheses is significantly proven to be accepted. Based on this information, it can be seen that only Trust variable is worth considering as the independent variable by explaining for $19.7 \%$ of purchase intention of female Millennial customers. Hence, Attitude can be excluded from the model for female consumers.

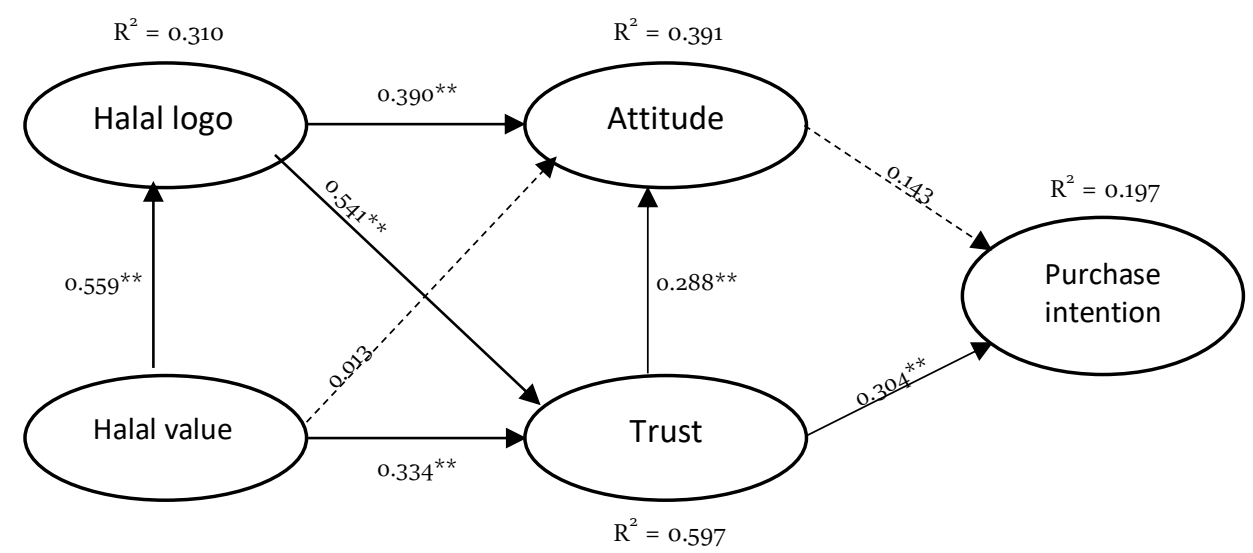

Note: Dashed lines signify non-significance; ${ }^{*} \mathrm{p}<0.01$

Figure 3. Female millennials

For male Millennial consumers, distinct results were obtained in which no direct impacts found on Halal value to Halal Logo and Trust; Halal Logo to Attitude, and Trust to Attitude. On the other hand, the significant direct impacts clearly exist in the relationships of Halal logo to Trust; Halal Value to Attitude; Attitude and Trust to Purchase Intention. Purchase intention of male consumers $\left(\mathrm{R}^{2}=0.285\right)$ explained by Attitude and Trust is at a better level compared to female consumers. 
Based on the findings, it can be concluded that male's purchase intention is considered less complex than female's since only four of eight hypotheses are proven to be significantly accepted.

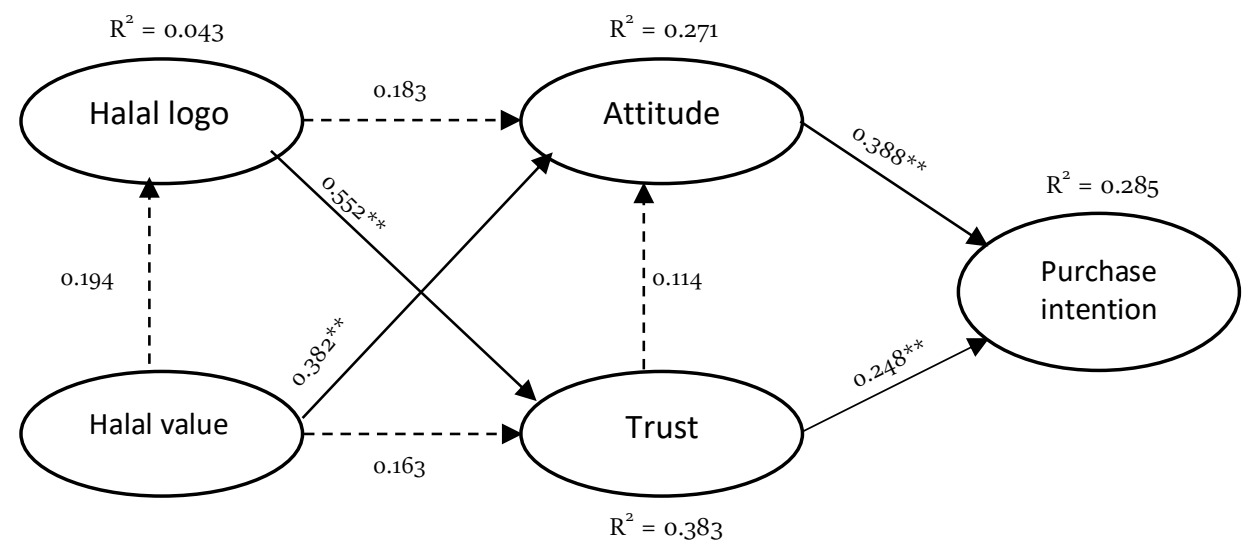

Note: Dashed lines signify non-significance. ${ }^{* *} \mathrm{p}<0.01$

Figure 4. Male millennials

Table 5. PLS results (multi group analysis)

\begin{tabular}{|c|c|c|c|c|c|c|c|c|c|}
\hline \multirow{2}{*}{ Hypothesis } & \multicolumn{3}{|c|}{ Female group } & \multicolumn{3}{|c|}{ Male group } & \multicolumn{3}{|c|}{ Differences } \\
\hline & $\begin{array}{l}\text { Direct } \\
\text { effect }\end{array}$ & $\begin{array}{l}\text { Indirect } \\
\text { effect }\end{array}$ & $\begin{array}{l}\text { Total } \\
\text { effect }\end{array}$ & $\begin{array}{l}\text { Direct } \\
\text { effect }\end{array}$ & $\begin{array}{l}\text { Indirect } \\
\text { effect }\end{array}$ & $\begin{array}{l}\text { Total } \\
\text { effect }\end{array}$ & $\begin{array}{l}\text { Direct } \\
\text { effect }\end{array}$ & $\begin{array}{c}\text { Indirect } \\
\text { effect }\end{array}$ & $\begin{array}{l}\text { Total } \\
\text { effect }\end{array}$ \\
\hline $\begin{array}{l}\text { Attitude } \rightarrow \text { Purc } \\
\text { hase intention }\end{array}$ & 0.143 & - & 0.143 & $0.388^{* *}$ & - & $0.388^{* *}$ & 0.245 & - & 0.245 \\
\hline $\begin{array}{l}\text { Halal } \log o \rightarrow \\
\text { Attitude }\end{array}$ & $0.390^{* *}$ & $0.156^{* *}$ & $0.546^{* *}$ & 0.183 & 0.063 & $0.246^{* *}$ & 0.207 & 0.093 & $0.300 *$ \\
\hline $\begin{array}{l}\text { Halal } \\
\text { logo } \rightarrow \text { Trust }\end{array}$ & $0.541^{* *}$ & - & $0.541^{* *}$ & $0.552^{* *}$ & - & $0.55^{* *}$ & 0.011 & - & 0.011 \\
\hline $\begin{array}{l}\text { Halal logo } \\
\rightarrow \text { Purchase } \\
\text { intention }\end{array}$ & - & $0.243^{* *}$ & $0.243^{* *}$ & - & $\begin{array}{c}0.233^{*} \\
*\end{array}$ & $0.233^{* *}$ & - & 0.010 & 0.010 \\
\hline $\begin{array}{l}\text { Halal } \\
\text { value } \rightarrow \text { Attitude }\end{array}$ & 0.013 & $0.402^{* *}$ & $0.415^{* *}$ & $0.382^{* *}$ & 0.066 & $0.49^{* *}$ & $0.369^{*}$ & $0.335^{* *}$ & 0.034 \\
\hline $\begin{array}{l}\text { Halal } \\
\text { value } \rightarrow \text { Halal } \\
\text { logo }\end{array}$ & $0.559^{* *}$ & - & $0.559^{* *}$ & 0.194 & - & 0.194 & $\begin{array}{c}0.365^{*} \\
*\end{array}$ & - & $\begin{array}{c}0.365^{*} \\
*\end{array}$ \\
\hline $\begin{array}{l}\text { Halal } \\
\text { value } \rightarrow \text { Trust }\end{array}$ & $0.334^{* *}$ & $0.303^{* *}$ & $0.637^{* *}$ & 0.163 & 0.107 & $0.270^{*}$ & 0.172 & $0.196^{*}$ & $\begin{array}{c}0.367^{*} \\
*\end{array}$ \\
\hline $\begin{array}{l}\text { Halal value } \rightarrow \\
\text { Purchase } \\
\text { intention }\end{array}$ & - & $0.253^{* *}$ & $0.253^{* *}$ & - & $\begin{array}{l}0.241^{*} \\
*\end{array}$ & $0.241^{* *}$ & - & 0.012 & 0.012 \\
\hline Trust $\rightarrow$ Attitude & $0.288^{* *}$ & - & $0.288^{* *}$ & 0.114 & - & 0.114 & 0.174 & - & 0.174 \\
\hline $\begin{array}{l}\text { Trust } \rightarrow \text { Purchase } \\
\text { intention }\end{array}$ & $0.304^{* *}$ & 0.041 & $0.345^{\star *}$ & $0.248^{* *}$ & 0.044 & $0.293^{* *}$ & 0.056 & 0.003 & 0.053 \\
\hline
\end{tabular}


The significant differences of effect of female and male groups due to moderating role of gender are shown in Table 5 and explained as follows:

1. Gender status significantly moderates Halal value to attitude and Halal value to Halal logo in direct effects.

2. Gender status has a significant mediating effect on Halal Value to Attitude and Halal Value to Trust in indirect effects.

3. Gender status shows a significant mediating effect on Halal logo to Attitude and Halal Value to Trust in total effects.

\section{DISCUSSION}

The results of this study confirm the significant importance of Halal value and logo in creating Muslim Millennials' trust and attitude as well as purchase intention towards halal products. First, the results point out that Halal value positively affects Halal logo (H6). This indicates that the benefits and features consumers gain from Halal foods (such as good standard at safety, health, and quality aspects) will eventually impact their demand on halal-certified foods (Majid et.al., 2015). The next findings show Halal value also has a positive and significant influence on Muslim Millennials' attitudes $\left(\mathrm{H}_{7}\right)$. Definitely, since Halal foods provide consumers with a high level of benefits (values), it will shape their positive attitude toward the halal foods. Furthermore, this study also confirms the positive and significant relationship between customer's trust, attitude and purchase intention ( $\left.\mathrm{H}_{1}, \mathrm{H}_{2}, \mathrm{H}_{3}\right)$. Moreover, it also confirms that the positive attitudes toward Halal products will also affect the consumers' trust as well as shape their buying intention (Bouhlel et al., 2011; Borzooei and Asgari, 2013; Delgado-Ballester \& Munuera-Alemán, 2005).

While the previous study found that consumer still has uncertain attitudes towards Halalcertified foods (Majid et.al., 2015), this study conversely confirms that the halal value positively affects trust (H8). This indicates that when the consumer gains the value or advantages from Halal food, his trust will increase and his uncertain attitudes towards halal products will reduce (Teng \& Wang, 2015; Wu \& Chen, 2005). The previous studies also support this research finding that confirms $\mathrm{H}_{5}$ since the Halal logo as a certification proof is still essential for a business to ensure and shape consumer's trust and positive attitude (Majid et.al., 2015; Janis, 2004). In addition, the last studies also confirm the $\mathrm{H}_{4}$, in which the halal logo gives significant positive impact on customer's attitude (Majid et.al., 2015; Golan, Kuchler, Mitchell, Greene, \& Jessup, 2001).

The remarkable finding of this study is different paths in explaining purchase intention of Halal food between female and male Millennial consumers. While the male consumer group considers trust and attitude as significant factors in determining purchase intention of Halal food, the female group only has trust. This finding contributes another confirmation to the previous study which says that the female behaviour is more emotionally focused, thus trust is considered as critical in shaping female consumer purchase intention (Kasambala et al., 2018; Orth et al., 2010). Moreover, since emotional or affective is considered as an element of trust, the customer's emotion will also impact his or her positive purchase intention (Harrisson and Voon, 2014; Tahir and Mohani, 2013). Thus, emotional bond to customers, particularly female consumers, can reinforce their trust as well as deepen their purchase intention of Halal food. Furthermore, even though male consumer considers trust and attitude, but still this study verifies that male has a greater beta value on attitude (which is identical with evaluation) than on trust. This result also confirms the last 
research that indicates that the higher level of emotion of women than men in their behaviour will result in their more favourable attitudes toward the product (Liao et al, 2009).

\section{CONCLUSION}

This study attempts to explain the consumer behaviour, particularly Indonesian Muslim Millennials, in terms of purchase intention of Halal certified foods. By heavily considering Halal food as a credence consumer good, this study develops a model which includes some relevant variables, i.e. Halal value, Halal logo, Trust, and Attitude. Apparently, these variables can be proved as significant independent variables for purchase intention directly and indirectly. The consumers' understanding of Halal value and Halal logo serves a necessary role as the antecedents of purchase intention. Meanwhile, Trust and Attitude show their mediating role between those antecedents with purchase intention.

However, the closer look to the data generated some interesting findings in terms of gender. In the female consumer group, only Trust can affect their purchase intention of Halal food. Both Halal logo and Halal value still can be considered as the antecedents of purchase intention since they significantly affect Trust. On the other hand, the male consumer group possesses attitude and trust as the necessary variables to explain the purchase intention of Halal food. In terms of antecedents, Halal value and Halal logo work in an independent way; Halal value affects Attitude and Halal Logo affects Trust. The moderating effect of gender occurs as follows: Halal value to attitude and Halal value to Halal logo (direct effects); Halal Value to Attitude and Halal Value to Trust (indirect effects); and Halal logo to Attitude and Halal Value to Trust (total effects).

\section{MANAGERIAL IMPLICATION}

As considering Halal food as a credence consumer good, this study indeed suggests that building consumer's trust is a worth way to influence Millennial's purchase intention of Halal certified food. Well-established trust in consumers can give a broader view in learning Millennials' behavior as the consumer of Halal certified food, besides learning consumer's attitude which is the common variable to tell. In detail, to establish good trust and attitude, the relevant stakeholders should perceive that consumer's understanding of Halal value and Halal logo can be the necessary things to give further attention. Herein, Halal value is observed as the fundamental understanding that Halal closely relates to safety, good quality, and hygiene, whereas Halal logo serves as the important tool in communicating Halal food provider's claim on Halal to their consumers. By comprehending these, a better success of Halal food providers shall gain better success in Halal food industry. Moreover, a different approach shall be taken to influence the purchase intention of Halal-food between female and male consumer groups since meaningful distinct paths exist within those groups.

\section{LIMTTATION AND FUTURE RESEARCH}

Apart from the findings, it is clear that this study has carried some limitations which can be addressed in future researches. First, this study used a relatively small sample size which not allowing the authors to run a more powerful statistical analysis, such as Structural Equation 
Modeling (SEM). It is encouraged for the future researchers to enlarge the sample size for more powerful statistical results. Second, this study only considered gender as the moderating variable in explaining the conceptual model, yet there are still other variables worth to examine, e.g. education level and income level. By considering it, a better explanation shall provide a broader explanation of Millennial's consumer behaviours in Halal food.

\section{REFERENCES}

Abdul Latiff, Z. A. B., Rezai, G., Mohamed, Z., \& Amizi Ayob, M. (2016). Food Labels' Impact Assessment on Consumer Purchasing Behavior in Malaysia. Journal of Food Products Marketing, 22(2), 137-146. doi: 10.1080/10454446.2013.856053

Ali, A., Xiaoling, G., Sherwani, M., \& Ali, A. (2017). Factors affecting Halal meat purchase intention: Evidence from international Muslim students in China. British Food Journal, 119(3), 527-541, doi: 10.1108/BFJ-10-2016-0455

Ali, A., Ali, A., Xiaoling, G., Sherwani, M., \& Hussain, S. (2018). Expanding the theory of planned behaviour to predict Chinese Muslims halal meat purchase intention. British Food Journal, 120(1), 2-17. doi: 10.1108/BFJ-05-2017-0278

Arham, M. (2010). Islamic perspectives on marketing. Journal of Islamic Marketing, 1(2), 149-164. doi: $10.1108 / 17590831011055888$

Ayyub, R. M. (2015). Exploring perceptions of non-Muslims towards Halal foods in UK. British Food Journal, 117(9), 2328-2343. doi: 10.1108/BFJ-07-2014-0257

Bashir, A. M., Bayat, A., Olutuase, S. O., \& Latiff, Z. A. A. (2019). Factors affecting consumers' intention towards purchasing halal food in South Africa: A structural equation modelling. Journal of Food Products Marketing, 25(1), 26-48. doi: 10.1080/10454446.2018.1452813

Bonne, K., \& Verbeke, W. (2008). Religious values informing halal meat production and the control and delivery of halal credence quality. Agriculture and Human Values, 25(1), 35-47. doi: 10.1007/s1046o-007-9076-y

Borzooei, M., \& Asgari, M. (2013). The Halal brand personality and its effect on purchase intention. Interdisciplinary Journal of Contemporary Research in Business, 5(3), 481-491.

Bouhlel, O., Mzoughi, N., Hadiji, D., \& Slimane, I. B. (2011). Brand personality's influence on the purchase intention: A mobile marketing case. International Journal of Business and Management, 6(9), 210. doi: 10.5539/ijbm.v6n9p210

Chin, W. W., Peterson, R. A., \& Brown, S. P. (2008). Structural Equation Modeling in Marketing: Some Practical Reminders. Journal of Marketing Theory and Practice, 16(4), 287-298. doi: 10.2753/MTP1069-6679160402

Dean, D., Suhartanto, D., \& Kusdibyo, L. (2019). Predicting Destination Image in Creative Tourism: A Comparative between Tourists and Residents. International Journal of Applied Business Research, 1(01), 1-15. doi: 10.35313/ijabr.v1io1.36

Del Giudice, T., Cavallo, C., \& Vecchio, R. (2018). Credence attributes, consumers trust and sensory expectations in modern food market: Is there a need to redefine their role? International Journal on Food System Dynamics, 9(4), 307-313. doi: 10.22004/ag.econ.277723

Delgado-Ballester, E., \& Munuera-Alemán, J. L. (2001). Brand trust in the context of consumer loyalty. European Journal of Marketing, 35(11/12), 1238-1258. doi: 10.1108/EUMooooooooo6475

dos Santos, C. P., \& Fernandes, D. V. der H. (2008). Antecedents and consequences of consumer trust in the context of service recovery. BAR - Brazilian Administration Review, 5(3), 225-244. doi: 10.1590/S1807-76922008000300005 
Fry, R. (2018, March 1). Millennials projected to overtake Baby Boomers as America's largest generation. Retrieved from: https://www.pewresearch.org/fact-tank/2018/03/01/millennials-overtake-babyboomers/

Golan, E., Kuchler, F., Mitchell, L., Greene, C., \& Jessup, A. (2001). Economics of food labeling. Journal of Consumer Policy, 24(2), 117-184. doi: 10.1023/A:1012272504846

Hair, J. F., Hult, G. T. M., Ringle, C., \& Sarstedt, M. (2016). A Primer on Partial Least Squares Structural Equation Modeling (PLS-SEM) (Second). SAGE Publications Inc.

Haque, A., Sarwar, A., Yasmin, F., Tarofder, A. K., \& Hossain, M. A. (2015). Non-Muslim consumers' perception toward purchasing halal food products in Malaysia. Journal of Islamic Marketing, 6(1), 133-147. doi: 10.1108/JIMA-04-2014-0033

Harrisson, Amat Tama, \& Boo Ho Voon. (2014). Components of Customer Emotional Experience with Halal Food Establishments . Procedia - Social and Behavioral Sciences 121. Pp. 272 - 280. doi: 10.1016/j.sbspro.2014.01.1128

Holdsworth, S., Sandri, O., Thomas, I., Wong, P., Chester, A., \& McLaughlin, P. (2019). The assessment of graduate sustainability attributes in the workplace: Potential advantages of using the theory of planned behaviour (TPB). Journal of Cleaner Production, 238, 117929. doi: 10.1016/j.jclepro.2019.117929

Ishak, S., Awang, A. H., Hussain, M. Y., Ramli, Z., Md Sum, S., Saad, S., \& Abd Manaf, A. (2016). A study on the mediating role of halal perception: Determinants and consequence reflections. Journal of Islamic Marketing, 入(3), 288-302. doi: 10.1108/JIMA-02-2015-0010

Jamal, A., \& Sharifuddin, J. (2015). Perceived value and perceived usefulness of halal labeling: The role of religion and culture. Journal of Business Research, 68(5), 933-941. doi: 10.1016/j.jbusres.2014.09.020

Jang, Y. J., Kim, W. G., \& Bonn, M. A. (2011). Generation Y consumers' selection attributes and behavioral intentions concerning green restaurants. International Journal of Hospitality

Management, 3o(4), 803-811. doi: 10.1016/j.ijhm.2010.12.012

Janis, Z.M., 2004. Malaysian Standard MS 1500: 2004 Halal Food-Production, Preparation, Handling and Storage-General Guidelines. Standards \& Quality News July-August, 2-3.

Kasambala, J., Kempen, E., \& Labschagne, J. (2018). The role of integral emotions in female consumers' clothing purchasing decision. The Retail and Marketing Review, 14(2), 16-27.

Lu, L., Bock, D., \& Joseph, M. (2013). Green marketing: what the Millennials buy. Journal of Business Strategy, 34(6), 3-10. doi: 10.1108/JBS-05-2013-0036

Liao, S. L., Shen, Y. C., \& Chu, C. H. (2009). The effects of sales promotion strategy, product appeal and consumer traits on reminder impulse buying behaviour. International Journal of Consumer Studies, 33(3), 274-284. doi: 10.1111/j.1470-6431.2009.00770.X

Lissitsa, S., \& Kol, O. (2016). Generation X vs. Generation Y - A decade of online shopping. Journal of Retailing and Consumer Services, 31, 304-312. doi: 10.1016/j.jretconser.2016.04.015

Majid, M. A. A., Abidin, I. H. Z., Majid, H. A. M. A., \& Chik, C. T. (2015). Issues of halal food implementation in Malaysia. Journal of Applied Environmental and Biological Sciences, 5(6), 50-56.

Marmaya, N., Zakaria, Z., \& Mohd Desa, M. N. (2019). Gen Y consumers' intention to purchase halal food in Malaysia: A PLS-SEM approach. Journal of Islamic Marketing. doi: 10.1108/JIMA-o8-20180136

Miharja, G. (2017). Muslims versus non-Muslims Purchasing Behavior towards Halal Products in Indonesia. Institut Teknologi Bandung. Mohamed, Z., Shamsudin, M. N., \& Rezai, G. (2013). The Effect of Possessing Information About Halal Logo on Consumer Confidence in Malaysia. Journal of International Food \& Agribusiness Marketing, 25(sup1), 73-86. doi: 10.1080/08974438.2013.800008

Mohamed, Z., Shamsudin, M. N., \& Rezai, G. (2013). The Effect of Possessing Information About Halal Logo on Consumer Confidence in Malaysia. Journal of International Food \& Agribusiness Marketing, 25(sup1), 73-86. doi: 10.1080/08974438.2013.800008 
Muhamad, N., Leong, V. S., \& Md Isa, N. (2017). Does the country of origin of a halal logo matter? The case of packaged food purchases. Review of International Business and Strategy, 27(4), 484-500. doi: 10.1108/RIBS-06-2017-0049

Mukhtar, A., \& Mohsin Butt, M. (2012). Intention to choose Halal products: the role of religiosity. Journal of Islamic Marketing, 3(2), 108-120. doi: 10.1108/17590831211232519

Nuttavuthisit, K., \& Thøgersen, J. (2017). The Importance of Consumer Trust for the Emergence of a Market for Green Products: The Case of Organic Food. Journal of Business Ethics, 140 (2), 323-337. doi: 10.1007/s10551-015-2690-5

Orth, Habil. Malkewitz, Ulrich R. Keven. \& Bee, Colleen (2010) Gender and Personality Drivers of Consumer Mixed Emotional Response to Advertising, Journal of Current Issues \& Research in Advertising, 32:1, 69-8o. doi: 10.1080/10641734.2010.10505276

Perrini, F., Castaldo, S., Misani, N., \& Tencati, A. (2010). The Impact of Corporate Social Responsibility Associations on Trust in Organic Products Marketed by Mainstream Retailers: A Study of Italian Consumers. Business Strategy and the Environment, 19, 512-526. doi: 10.1002/bse.66o

Pomarici, E., \& Vecchio, R. (2014). Millennial generation attitudes to sustainable wine: An exploratory study on Italian consumers. Journal of Cleaner Production, 66, 537-545. doi: 10.1016/j.jclepro.2013.10.058

Reuters, T. (2018). State of the Global Islamic Economy.

Saeed, M., \& Azmi, I. A. G. (2019). A cross-cultural study of staying reasons of American brands: Analysis of millennial Muslim consumers. Journal of Islamic Marketing, 1O(1), 249-268. doi: 10.1108/JIMA-08-2017-0086

Sheldon, I. M. (2017). Certification Mechanisms for Credence Attributes of Foods: Does It Matter Who Provides Diagnosis? Annual Review of Resource Economics, 9(1), 33-51. doi: 10.1146/annurevresource-100516-053630

Sherwani, M., Ali, A., Ali, A., Hussain, S., \& Zadran, H. G. (2018). Determinants of muslim consumers' Halal meat consumption: Applying and extending the theory of planned behavior. Journal of Food Products Marketing, 24(8), 960-981. doi: 10.1080/10454446.2018.1450173

Spehar, C. (2006). Marketing to teens: Hip 2 B green. Natural Foods Merchandiser, 2ך(10), 45-56.

Suhartanto, D., Dean, D., Leo Gundur, \& Triyuni, N. N. (2019). Millennial Experience with Online Food Home Delivery: A Lesson from Indonesia. Interdisciplinary Journal of Information, Knowledge, and Management, 14, 277-294. doi: 10.28945/4386

Tahir, I. R., \& Abdul, M. (2013). The role of religious orientation in the business performance of women owned firms: a preliminary study in Malaysia halal food industry. A multidisciplinary journal of global macro trends, 2, 40-45.

Teng, C.-C., \& Wang, Y.-M. (2015). Decisional factors driving organic food consumption. British Food Journal, 11入(3), 1066-1081. doi: 10.1108/BFJ-12-2013-0361

Thomas, P. and Selimovic, A. (2015). "Sharia on a Plate?" A critical discourse analysis of halal food in two Norwegian newspapers. Journal of Islamic Marketing, 6(3), 331-353. doi: 10.1108/JIMA-052014-0041

Tieman, M. (2011). The application of Halal in supply chain management: In-depth interviews. Journal of Islamic Marketing, 2(2), 186-195. doi: 10.1108/17590831111139893

Valentine, D. B., \& Powers, T. L. (2013). Generation Y values and lifestyle segments. Journal of Consumer Marketing, 3o(7), 597-6o6. doi: 10.1108/JCM-07-2013-0650

Vanany, I., Soon, J. M., Maryani, A., \& Wibawa, B. M. (2019). Determinants of halal-food consumption in Indonesia. Journal of Islamic Marketing. doi: 10.1108/JIMA-o9-2018-0177

Verbeke, W., Rutsaert, P., Bonne, K., \& Vermeir, I. (2013). Credence quality coordination and consumers' willingness-to-pay for certified halal labelled meat. Meat Science, 95(4), 790-797. doi: 10.1016/j.meatsci.2013.04.042 
Wu, I.-L., \& Chen, J.-L. (2005). An extension of Trust and TAM model with TPB in the initial adoption of on-line tax: An empirical study. International Journal of Human-Computer Studies, 62(6), 784-808. doi: 10.1016/j.ijhcs.2005.03.003 